\title{
SIGNIFICADOS DO DIREITO AO VOTO POR PARTE DE PRESOS PROVISÓRIOS E ADOLESCENTES INTERNADOS
}

\author{
MEANINGS OF THE RIGHT TO THE VOTE BY INMATES AND YOUNG \\ OFFENDERS
}

\author{
Eder Aparecido de Carvalho ${ }^{1}$, Alexandre da Silva de Paula² e Sérgio Kodato ${ }^{3}$ \\ ${ }^{1}$ Instituto Federal Catarinense, Campus Brusque, Brasil, e-mail: carvalhoeder@hotmail.com \\ 2 Instituto Federal de São Paulo, Campus Votuporanga, Brasil, e-mail: aledpaula@outlook.com \\ ${ }_{3}^{3}$ Universidade de São Paulo, Faculdade de Filosofia, Ciências e Letras de Ribeirão Preto, Programa \\ de Pós-Graduação em Psicologia, Brasil, e-mail: skodato@ffclrp.usp.br.
}

\author{
ARTICLE INFO \\ Article history: \\ Received 2019-12-17 \\ Accepted 2020-06-20 \\ Available online 2020-06-20
}

\begin{abstract}
Palavras-chave: Democracia. População Carcerária. Prisão Provisória. Direitos Políticos.

Keywords: Democracy. Inmate Population. Provisional Prison. Politic Rights.
\end{abstract}

RESUMO. Este estudo investiga significados e argumentos com relação ao direito de votar e escolher seus representantes, por parte de presos provisórios e adolescentes maiores de 16 anos que cumprem a medida socioeducativa em regime de internato. Objetiva-se compreender os conceitos e representações que circulam no imaginário social, sobre o pleno direito do cidadão privado de liberdade de exercer sua cidadania. Referenciando-se no método monográfico, buscou-se uma revisão bibliográfica de textos e documentos referentes aos aspectos atuais do Código Eleitoral Brasileiro e a relação entre o direito ao voto, formação da cidadania e reinserção social de encarcerados.

ABSTRACT. This research investigates meanings and arguments the right to vote and choose their representatives by pre-trial detainees and adolescents over 16 years old who fulfill the socio-educational measure in internment. The objective is to understand the concepts and representations that circulate in the social imagination, about the full right of citizens deprived of freedom to exercise their citizenship. Referring to the monographic method, a bibliographic review of texts and documents related to the current aspects of the Brazilian Electoral Code was sought, and the relationship between the right to vote, citizenship formation and social reinsertion of prisoners.

\section{Introdução}

O propósito deste artigo consiste em compreender as relações entre o exercício da cidadania, configurada pelo acesso aos direitos políticos dentro do universo carcerário, e o processo de reinserção social do encarcerado. Buscou-se examinar significados e estudos referentes ao direito ao voto de encarcerados e confrontar os argumentos críticos (contrários), com os argumentos favoráveis (de defesa), no que se refere às resoluções governamentais 
que, desde 2010, r̂têm permitidoò o voto de presos provisórios e de adolescentes que cumprem medida socioeducativa em regime de internação.

A pesquisa se inspira no método monográfico que, de acordo com Marconi e Lakatos (2010, p. 93), r̃ ronsiste no estudo de determinados indivíduos, profissões, condições, instituições, grupos ou comunidades, com a finalidade de obter generalizaçõesò $A$ investigação examina o tema escolhido, observa os fatores que influenciam e os analisa nos aspectos que promovem tanto a negação, como a afirmação dos direitos. O método consiste em examinar particularidades, mas pode, também, abranger o conjunto de atividades de um grupo, por exemplo, o estudo de jovens encarcerados.

O recorte empírico da pesquisa se limitou a buscar articular as experiências e saberes advindos da intervenção institucional, por parte dos autores deste artigo, em presídios e instituições de internação para adolescentes infratores, com a literatura científica, textos teóricos e documentos oficiais. O estudo ampara-se num levantamento de documentos oficiais referentes a temática em questão, no período de 2000 até 2018 e, ainda, uma revisão bibliográfica, tendo como propósito uma abordagem crítica do objeto de estudo.

Partiu-se de algumas questões enquanto norteadoras: os presos provisórios (aqueles que estão presos, mas não condenados, e que poderão, até mesmo, ser absolvidos ao término do processo) e os adolescentes que cumprem medida socioeducativa em regime de internação têm ou não direito a votar e como isso se reflete em sua cidadania? A oportunidade destes sujeitos de participarem do processo democrático de escolha de seus representantes exerce influência no processo de reinserção social?

Procura-se ainda: compreender os argumentos contrários e os favoráveis à situação de inclusão dos presos no processo eleitoral. Essas questões foram trabalhadas de maneira introdutória, com a devida parcimônia e respaldo nos documentos que respaldam a lei vigente, sem a pretensão de esgotar o conhecimento sobre a temática em sua complexidade.

\section{Fundamentação teórica}

\subsection{Universalização do voto: presos provisórios e adolescentes internados}

Se a democracia significa r̃governo do povoò complementa-se que o voto popular contribui junto à participação ativa na vida pública ï mesmo que tal ação seja insuficiente ${ }^{1}$.

\footnotetext{
${ }^{1}$ Dependendo do contexto r̃governo do povoò espelha as praças tomadas pelos cidadãos da Grécia Antiga (mais especificamente em Atenas), a fim de participar de maneira direta junto às decisões da comunidade ï democracia direta (CARVALHO, 2006). Por outro lado, seguindo Weber (2000) e Bobbio (2000), hoje, se encaixa melhor como governo dos representantes do povo, pois se restringiu a participação popular, e a democracia passa a ser vista como um procedimento eleitoral para escolha dos representantes ï democracia indireta (representativa).
} 
Não tendo qualquer objetivo de descartar a democracia representativa, indispensável na vida contemporânea, o artigo que segue aborda o direito da soberania popular ativa, incluindo os segmentos marginalizados e excluídos socialmente. Com efeito, isso não significa efetivar a participação total do povo junto à vida pública, ou seja, dizer que o povo abandonaria suas atividades privadas a fim de se envolver com a administração pública (BOBBIO, 2000).

Cabe ao povo soberano ${ }^{2}$ participar dos processos decisórios do poder e escolha de seus representantes no Governo. O conceito de democracia é muito amplo, e a ideia é se restringir ao campo da participação eleitoral ${ }^{3}$. Contudo, nas relações de poder, inclusive num momento decisivo como as eleições democráticas, nota-se a pertinência de uma apreciação sobre os conceitos de minoria e maioria. Esse fato decorre do reconhecimento de que, no Brasil, há grupos sociais organizados, altamente influentes nas decisões coletivas sobre o pleito eleitoral, que disseminam discursos alinhados a interesses corporativistas, em detrimento do bem comum.

E, do ponto de vista conceitual, pode-se afirmar que as minorias são grupos sociais considerados em sua existência na fronteira social, ou mesmo fora dela, ou seja, grupos marginais (ROSO, et al., 2002). Em Psicologia Social, a partir dos estudos em Representações Sociais (Moscovici, 2009), compreende-se o conceito de minoria como grupo que busca reconhecimento social em uma sociedade dinâmica, em detrimento das teorias sociais pautadas na estratificação ou diferenciação.

A situação de uma minoria é a situação de um grupo ao qual foi negada autonomia e responsabilidade, que não tem a confiança, nem é reconhecido por outros grupos, tanto porque ele é dominado, ou devido a sua posição dissidente etc. Tal grupo não se reconhece nos sistemas existentes de poder, crença e não representa tal sistema para ninguém. A fim de fornecer um sistema diferente de crenças, de obter poder ou se tornar um modelo para outros, tal grupo tem de ser capaz de influenciar os outros, mudando sua maneira de ver e/ou agir, até que chegue ao ponto de se tomar uma maioria (MOSCOVICl, 2009, p. 371).

Neste sentido, afirma-se que minorias são grupos discriminados e marginalizados dentro da sociedade através de sua ideologia e instituições, devido aos aspectos econômicos, sociais, culturais, físicos, sexuais, morais ou religiosos.

\footnotetext{
${ }^{2} \mathrm{O}$ conceito de soberania popular, obedecendo ao que rege a doutrina clássica, diz respeito a uma organização política onde todos decidem sobre tudo. Obedece ao conceito de r̃democracia dos gregosò ï poder do povo. O princípio da soberania popular em nosso país é definido no 1a artigo da Carta Magna de 1988 - ñodo poder emana do povo, que o exerce por meio de representantes, ou diretamenteò Espécie de democracia semidireta (SILVA, 2006, p.46).

${ }^{3}$ Importante explicar que a participação eleitoral (apenas ela) é insuficiente. Participação ativa não se esgota em um sufrágio emitido a cada quatro anos. O voto, muita das vezes, corresponde a um instrumento limitado de participação e acaba por servir apenas como ritual para consolidar (legitimar) a classe dominante no poder (CARVALHO, 2006).
} 
Uma maioria é definida politicamente pela quantidade, maioria simples ou proporcional. Antes, porém, de ser caracterizada por uma expressão numérica, uma maioria é um padrão, um ñAlguémò onde o senso comum aprisionou determinados caracteres e ao qual os indivíduos devem-se enquadrar através da exclusão ou submissão de outros caracteres [...]. As minorias são ñmultidõesòcuja organização desestabiliza o consenso da maioria e sua ordem política (CARDOSO-JUNIOR, 2012, p. 160/).

As eleições estão muito além de uma mera rotatividade de governos. Trata-se de um processo com significado para além da alternância de poder. Uma eleição maximiza o essencial da democracia: que o poder não pertence aos ocupantes do governo, podendo ser revogado (via eleitoral), caso o representante não cumpra com o que the foi delegado e prometido em sua agenda apresentada ao povo. As ideias ï vontades ï da maioria e da minoria no âmbito democrático precisam ser garantidas e respeitadas pela lei. Por outro lado, sabe-se o quanto a sociedade brasileira desenvolveu-se em meio ao dissenso, ao constante conflito entre maioria e minoria. Mas a democracia é uma forma de organização política (talvez a única) que contempla o conflito como legítimo ī legalizado (CHAUI, 2000).

$\mathrm{Na}$ sociedade atual, nota-se a crescente complacência coletiva e a indiferença de muitos indivíduos diante da violência que atinge as minorias e atravessa as relações desiguais entre homens e mulheres. Há uma apatia de ñodos que, como se sabe, está embebida no ódio que se alastra sorrateiramente por todo o tecido socialò (CANIATO, 2003, p. 78). Esse sentimento aversivo, que deprecia as minorias e criminaliza ações coletivas no conjunto das pautas inclusivas, tem sido disseminado por grupos políticos cujo interesse é alinhar o Estado e a sociedade ao poder repressivo. E, assim, justificar o uso da violência letal como tática de guerra para a manutenção da ordem pública, ou seja, a solução para apaziguar conflitos urbanos com graves repercussões na sociedade. E, de fato, é neste contexto que os rumos da democracia no país são discutidos, estrategicamente, por candidatos ao pleito eleitoral.

Dentro da democracia, os cidadãos são sujeitos de direitos e onde tais direitos não estejam garantidos, tem-se o direito de batalhar por eles. Isso se chama democracia. Quando a democracia surgiu na r̃Grécia Antigaò mais especificamente em Atenas, estabeleceu-se que todos os cidadãos têm os mesmos direitos e, por isso, devem ser tratados de maneira igual ï igualar os desiguais. É sabido, no entanto, que uma simples declaração de direitos não faz emergir os iguais, porém, propicia o campo de abertura para sua reivindicação.

Segundo Cardoso-Junior (2012, p. 162), r̃a busca pelo consenso e pela opinião, que são mecanismos políticos de votos, está igualmente envolvida por dispositivos de disciplina ou controle, conforme o caso, onde as subjetividades e as opiniões são moldadasò Cabe às minorias ativas ocuparem o espaço no debate público, sobre direitos e deveres, militando de forma organizada e consciente, para que o processo democrático seja garantido com a participação e representação de todos os seguimentos da população, com destaque para as camadas mais excluídas. É notório também que ñodo cidadão tem o direito de expor em 
público seus interesses e opiniões, vê-los debatidos pelos demais e aprovados ou rejeitados pela maioria, devendo acatar a decisão tomada publicamenteò(CHAUI, 2000, p. 559). Para a autora citada, do ponto de vista político, afirma-se que todos os cidadãos têm competência para opinar e decidir sobre os interesses e direitos da própria pólis.

Inspirando-se nesse contexto discursivo (Grécia Antiga), várias instituições civis, desde 1982, vêm lutando pelo direito do voto do preso, tanto em relação aos presos provisórios ï que ainda não tiveram condenação criminal definitiva ï quanto aos adolescentes internados ${ }^{4}$. Cabe ressaltar que o artigo 136 do Código Eleitoral assegura a instalação de seções eleitorais nos estabelecimentos de internação coletiva. Isso sem dizer que a Constituição Federal suspende direitos políticos rãpenasòpara o condenado com sentença transitada em julgado ï Art. 15, III, CF/1988.

Por sua vez, as resoluções reeditadas a cada pleito pelo Tribunal Superior EleitoralTSE acabam por estabelecer que os presos provisórios podem votar, se possível. Neste âmbito, já tratado por Camargo (2009), um direito político é subordinado a uma determinada condição. São apontados, mesmo que indiretamente, entraves de natureza técnica: preso é de unidade prisional distinta do domicílio eleitoral, alta rotatividade dos presos (o que dificulta garantir o direito do preso de votar), motivos de segurança etc. Isso sem trazer a exigência mínima de 20 eleitores por estabelecimento prisional ou unidade de internação ${ }^{5}$. Os presos provisórios (dentro daquilo que está estabelecido) têm dificuldades até para justificar a ausência no pleito.

Importante esclarecer que nas eleições de 2016, e com propósito de viabilizar o voto de presos provisórios e de jovens em medida socioeducativa de internação, a Resolução do TSE, 23.461/2015, dispôs sobre as regras de instalação de seções eleitorais especiais em estabelecimentos prisionais e em unidades de internação de adolescentes. No pleito de 2018, por sua vez, foi (visto que tais resoluções têm sido reeditadas a cada pleito) a Resolução do TSE de n. 23.554/2017 que disciplinou sobre a instalação das seções eleitorais especiais, e um dos critérios, mais uma vez, é os estabelecimentos prisionais e as unidades de internação contarem com, no mínimo, vinte eleitores aptos a votar ${ }^{6}$.

\footnotetext{
${ }^{4}$ Para o devido esclarecimento sobre esse assunto, é importante frisar que existem duas modalidades de presos. Os que estão aguardando o devido julgamento (esperando pela condenação ou absolvição), e os que já estão encarcerados por ensejo de uma sentença penal condenatória definitiva. Os que estão presos e não foram julgados enquadra-se naquilo que chamamos de presos provisórios (COSTANZE, 2008; TSE-Resolução 23.461/2015; TSE-Resolução 23.554/2017).

${ }^{5}$ Números de eleitores presos/internados, exigidos (mínimo), por estabelecimento prisional ou unidade de internação, já foram 30 e 50.

${ }^{6}$ O Tribunal Superior Eleitoral passou a regulamentar (desde 2010 ï Resolução 23.219/2010), por meio de resoluções (adaptadas a cada eleição), o exercício deste direito dos presos provisórios e adolescentes internados: votar.
} 
Em 2016 o Brasil possuía, segundo o Ministério da Justiça (Departamento Penitenciário Nacional: Informações Penitenciárias ï INFOPEN), 726.712 pessoas privadas de liberdade, 97\% acima daquilo que comporta as prisões brasileiras. Deste total, 40,2\% (292.450 presos) aguardavam julgamento, ou seja, eram presos provisórios. Um quarto deles, 75.862 mil, estava em São Paulo (distribuídos em cerca de 400 unidades prisionais), mais importanteòEstado da Federação. Neste mesmo ano, segundo dados do Sistema Nacional de Atendimento Socioeducativo ï SINASE, havia 18.567 mil adolescentes em situação de internação ${ }^{7}$.

Passados vinte anos da vigência do paradigma da Doutrina da Proteção Integral na relação com a infância e a juventude (traduzido na legislação brasileira pelo Estatuto da Criança e do Adolescente/ECA, de 1990), as demandas sociais pelo r̃controleò da criminalidade juvenil ainda têm se desdobrado em processos crescentes de criminalização, como nos indica o persistente clamor pela redução da idade penal, e de patologização do adolescente em conflito com a lei [...] (ROSA; VICENTIN, 2010, p. 110).

É prudente esclarecer que o voto de presos provisórios e de adolescentes que cumprem medidas socioeducativas, obedecendo ao que exige as resoluções aprovadas nos meses que antecedem cada pleito (têm sido reeditadas no ano que antecede cada eleição), muitas vezes, se apresenta sob questionamento (partindo de um ponto de vista mais crítico), contrário às resoluções e mesmo ao disposto no Código Eleitoral e na Constituição Federal. A população carcerária, no exercício da democracia, pode ser vista como um tipo de rólevirminoritárioò capaz de ensejar resistências ou linhas de fuga aos dispositivos disciplinares e de captura das maiorias democráticas (CARDOSO-JUNIOR, 2012).

\section{Discussão}

As justificativas em oposição ao voto da população carcerária que emergiram nas intervenções institucionais dos autores, desfilam os seguintes argumentos:

- Essa população não tem consciência política, visto que alguns dos encarcerados não condenados e alguns adolescentes sob medidas socioeducativas estão distantes do seio da sociedade há mais de ano, votariam de forma aleatória e/ou mesmo nos ñpioresòcandidatos. Fatalmente muitos dos presos provisórios e adolescentes internados chegarão frente à frente da urna sem meditar em qual candidato votar. Voto sem convicção. Sem dizer que muitos ï presos provisórios e adolescentes internados ï podem sentir-se desmotivados pela situação em que se encontram.

\footnotetext{
${ }^{7}$ Para efeito de informação, a maior unidade federativa (São Paulo) possuía em 2016, segundo dados do Sistema Nacional de Atendimento Socioeducativo (SINASE), 9.572 mil menores infratores. Aqui estão contabilizados os que estão em condição de internação, semiliberdade, internação provisória, atendimento inicial e internação-sanção.
} 
- É sabido que um cidadão no seio da sociedade já apresenta dificuldades para definir o nome de seu candidato, principalmente nas eleições legislativas, dado o número de candidatos. Imagina os presos provisórios e adolescentes internados, distantes, muitas das vezes, dos meios de comunicação (propaganda eleitoral gratuita) ${ }^{8}$.

- Existe também ï principalmente por autoridades de São Paulo e Rio de Janeiro com grande população carcerária ï um temor no que diz respeito à possibilidade de interferência de facções criminosas no voto de presos. Assim, outro fato a levar em conta é que muitos destes votariam pressionados por facções criminosas, a fim de representar os seus interesses de alguma forma.

- Outro temor diz respeito à segurança, ou seja, sob que condições orquestrarão o que pedem as resoluções reeditadas. Há possibilidade de viabilizar equilíbrio entre direito e segurança ou simplesmente corre-se o risco?

- O país possui ainda, além dos presos aguardando julgamento, 18.567 jovens e adolescentes entre 16 e 21 anos submetidos à medida socioeducativa ī internação ${ }^{9}$. Estes também são abrangidos pela resolução o que dificulta ainda mais a operação.

- Outra questão tormentosa é como operacionalizar o processo eleitoral dentro das unidades penais e instituições socioeducativas, pois são necessários muitos mesários voluntários. Será que teremos voluntários em número suficiente para atender a todos os estabelecimentos? $\mathrm{O}$ TRE/SP chegou a afirmar, em determinado momento, a necessidade de mais de 4 mil mesários apenas para o Estado de São Paulo. Veja que a logística para preparar as seções e instalar as urnas eletrônicas aparece como outro empecilho.

Para fins de informação, das 432.960 seções eleitorais (eleições municipais de 2016), apenas 121 foram destinadas para a votação de 5.973 eleitores nesta situação ï privado de liberdade (TSE, 2016a). Enquanto São Paulo correspondia à quase metade das seções (56), Rio, Distrito Federal, Rio Grande do Norte, Alagoas e Tocantins não garantiram (por meio dos TREs) seções destinadas a assegurar a participação desse público ${ }^{10}$.

\footnotetext{
${ }^{8}$ Esclarece-se que muitas das celas dos presos provisórios (respeitado algumas variações de Estado para Estado ou até mesmo variações entre algumas Instituições Penais) possui televisão. Isso ocorre, após autorização da direção, quando algum dos integrantes da cela possui condição de adquiri-la. Cada cela pode ter uma televisão. Também é permitido um rádio. As instituições de adolescentes internados também não fogem à regra.

${ }^{9}$ Considerados os adolescentes que estão sob medidas socioeducativas (internação, semiliberdade, internação provisória, atendimento inicial e internação-sanção), o país apresentava no final de 2016 ï segundo dados do SINASE, 26.450 adolescentes infratores (ato infracional).

10 Embora se trate de números que podem ser melhorados, também é possível enxergar avanços (mesmo que lentos) no que tange a esse processo: em alguns Estados, como Acre, Pará, Pernambuco e Sergipe, já existe esse tipo de votação desde 2002. Em 2004, 06 Estados tiveram votação de presos provisórios. Em 2006, subiu para 10 Estados. Em 2008, 11 Estados tiveram votação de presos provisórios. Os outros 15 Estados e o Distrito Federal vinham sistematicamente negando esse direito, mas em 2010 respeitando a Resolução 23.219/2010 praticamente todos os Estados se organizaram para esse tipo de votação ï aproximadamente, 18.928 presos provisórios participaram das eleições em
} 
O voto de presos provisórios, obedecendo àquilo que exige as resoluções reeditadas (soma-se o disposto na Carta Magna e Código Eleitoral), também possui os seus defensores. Partindo de um ponto de vista favorável (de defesa) à medida, é possível citar os seguintes argumentos:

- Especialistas reconhecem que se as dificuldades em São Paulo são maiores, as estruturas também são. O que não pode persistir é o discurso do r̃se possívelò até porque Estados menores, com menos estrutura, já realizam a votação em unidades prisionais.

- Se o momento mais alto da liberdade, em um regime democrático, consiste no voto, então por que privar o preso provisório de direito, uma vez que a Constituição Federal vigente (desde 1988) garante o princípio da presunção da inocência ì todos são inocentes até uma deliberação (sentença) judicial definitiva, não importando se houve (ou não) o flagrante, se existem (ou não) provas ou se a opinião pública está contra ou a favor do acusado.

- Mais que o direito, o preso provisório (inclui o adolescente sob medida socioeducativa) possui um dever, uma vez que ele não pode abrir mão (renunciar) da liberdade privada com consequências públicas. Essência de ordem constitucional.

- Fundamentando-se no princípio da obrigação legal (voto obrigatório e não facultativo), é certo afirmar que o encarcerado tem seus direitos, mas ao mesmo tempo, tem os seus deveres, o que obriga o preso provisório (inclui adolescentes internados entre 18-21 anos), seguindo o que exige a legislação, a votar.

- Sobre a alegação das autoridades de que o indivíduo, estando encarcerado, não teria condições de ter conhecimento das propostas apresentadas pelos candidatos, pelo fato de muitas vezes não ter acesso à televisão e ao rádio, ou até mesmo não ter possibilidade de receber a visita dos candidatos às cadeias para lá fazerem seus comícios, impõe que justo seria as autoridades (Instituições e o Estado) conscientizarem-se das condições em que os acautelados estão e mudarem a forma de tratá-los ${ }^{11}$.

- Sobre como operacionalizar o processo eleitoral, e a afirmação que faltaria mesários, é importante esclarecer que bastaria permitir (haja vista o impedimento expresso nas últimas resoluções reeditadas) a participação de mesários recrutados das próprias unidades penais: agentes de segurança penitenciária, assistentes sociais, psicólogos etc. É claro que também faz parte do processo colocar em ordem o documento eleitoral e pessoal do preso em tela.

335 seções eleitorais distribuídas pelo país. Naquele ano, apenas Goiás não participou, alegando motivos de segurança. No entanto, aqui (a partir de 2010) também começa a preocupação, visto que em 2012, apenas 8.871 foi a quantidades de presos provisórios que votaram nas 394 seções eleitorais. Enquanto em 2014, 162 zonas eleitorais garantiram o voto de 14.190 presos provisórios e adolescentes infratores (TSE, 2010a; TSE, 2016a). Ou seja, trata-se de número de votantes inferior ao disposto no pleito de 2010.

11 Importante frisar que boa parte dessas justificativas não é coerente, uma vez que a maioria dos presídios (cadeias e penitenciárias) possui televisão e rádios. Sem falar do contato com os familiares durante as visitas semanais. Enfim, estão presos, mas não isolados do mundo. 
A questão é polêmica. Os presos provisórios e os adolescentes sob medidas socioeducativas têm direito a votar? A Carta Magna assegura a todos os direitos políticos e determina a obrigatoriedade do alistamento eleitoral e do voto aos maiores de idade $\overline{1}$ dezoito anos (inclui aqui os condenados não em definitivo). O Código Eleitoral (Lei 4.737/65) também penaliza a todos que, obrigados a votar, não se justificam diante da Justiça Eleitoral em até 30 (trinta) dias, depois da consumação do pleito. Triste realidade, pois o próprio Estado (aquele que deveria coibir os crimes) impede aqueles que estão presos, mas não condenados, e que poderão, até mesmo, ser absolvidos ao término do processo, de votar. Veja que têm os seus direitos cerceados pelo próprio Estado. O pretexto é quase sempre o mesmo, falta de estrutura (impossibilidade de implantação de seções eleitorais especiais) para colher os votos. Os direitos civis e políticos são frontalmente atingidos (COSTANZE, 2008).

Não há, no ordenamento jurídico pátrio, previsão que impeça o preso provisório de votar, tampouco de suspensão do seu direito político, visto que esta ocorre somente na hipótese de condenação transitada em julgado. No entanto, a realidade do sistema carcerário vai no sentido contrário, posto que impeça o exercício de participação ativa na democracia, ao indivíduo que esteja cautelarmente preso (RANGEL-JUNIOR; NOBREGA, 2018, p. 46).

Saliente recordar que a Resolução 23.219 possibilitou em 2010, entre presos provisórios e adolescentes em unidades de internação, o alistamento de 20.099 eleitores ${ }^{12}$. Aptos (na ocasião) 424 estabelecimentos prisionais ${ }^{13}$ e unidades de internação de adolescentes, em 25 Estados e o DF. Entre os Estados alistados não se tinha, alegando motivos de segurança, Goiás ${ }^{14}$. Estavam alistados os adolescentes, entre 16 e 21 anos, que cumpriam medida socioeducativa de internação e presos que ainda não tinham condenação criminal definitiva.

${ }^{12}$ Anteriormente, a fim de implementar o voto do preso não condenado, o TSE já tinha editado a Resolução $n$. - 22.712/2008. Estabelecia que juízes eleitorais, sob a coordenação dos TREs, poderiam criar seções eleitorais especiais em presídios, a fim de respeitar o direito ao voto. O que parece é que a maioria dos TREs (até então) não tinham se mobilizado, assim foi editada a Resolução 23.219/2010, o que propiciou uma eleição coordenada nesse sentido. De lá para cá, as resoluções emitidas pelo TSE (já mencionado neste texto) têm sido reeditadas a cada eleição.

${ }^{13}$ O TSE determinava (assim funciona até os dias atuais) que as seções eleitorais somente fossem instaladas em estabelecimentos onde houvesse uma quantidade mínima de 20 eleitores aptos a votar. E o encarcerado que no dia do pleito já tiver uma sentença condenatória definitiva ficará impedido de participar da votação.

${ }^{14}$ As resoluções que disciplinam a instalação de seções eleitorais especiais em estabelecimentos prisionais e em unidades de internação de adolescentes nas eleições (até mesmo as mais atuais e que vão sendo reeditadas a cada pleito) esclarecem que não será colhido o voto onde os Tribunais Regionais Eleitorais (TREs) apontarem a inviabilidade de realização da eleição, ou em presídios ou unidades de internação, por falta de condições de segurança. Ou seja, o direito de voto desses eleitores será assegurado, desde que a segurança não seja colocada em risco. 
Apesar de não ter sido novidade em nosso país, em 2010 foi a primeira vez que o voto do preso provisório, e adolescente que cumpre medida socioeducativa de internação, aconteceu de maneira coordenada em todo o país. Importante salientar que desde então não houve ocorrência de nenhum incidente, mas ainda há muito o que conquistar, pois os 5,9 mil eleitores alistados, dentro das condições abordadas no texto (121 seções eleitorais em 22 unidades federativas $і ̈ 1^{\circ}$ turno do pleito 2016$)^{15}$, representam pouco perto dos 292.450 mil presos provisórios e 18.517 jovens e adolescentes internados ī entre 16 e 21 anos $^{16}$. Sendo assim, o negócio é continuar as lutas populares e forçar a ampliação dos direitos políticos.

\section{Considerações finais}

Toda democracia é passível de aperfeiçoamento, retirar ou cercear o direito de votar de um indivíduo acautelado prejudica o Estado democrático de direito e os princípios de cidadania de uma nação. O encarcerado, mesmo sob custódia do Estado, sofre as implicações de todo tipo de decisão tomada fora do âmbito prisional, por isso parece ser coerente os presos provisórios terem direito de eleger o seu representante no Executivo e no Legislativo. A condição de preso, provisório temporariamente retira-o de seu convívio com a sociedade, mas não o desconecta do mundo em que vivemos e nem lhe retira seus direitos políticos.

É preciso que a sociedade, como um todo, perceba o preso provisório e o adolescente sob medida socioeducativa como parte de um campo (esfera) de relacionamento público. Isso contribui junto ao avanço gradual de processo democrático. Importante acentuar a responsabilidade de cada indivíduo. Nenhuma manifestação de cidadania é mais própria (verdadeira) que o voto. Quanto maior o número de pessoas participando do processo, mais favorável a construção de um país comum a todos.

A Carta Magna do nosso Brasil qualifica o voto como direito fundamental para todos que preservam seus direitos políticos ï exatamente o caso dos presos não condenados (provisórios) e adolescentes sob medidas socioeducativas. Estes não perdem os direitos políticos

\footnotetext{
${ }^{15}$ Relevante esclarecer que dos 5,9 mil eleitores alistados no $1^{\circ}$ turno das eleições 2016 (eleições municipais), apenas 4,1 mil votaram. Já no segundo turno mais de mil presos provisórios e adolescentes internados conseguiram votar para eleger os prefeitos e vice-prefeitos. No $2^{\circ}$ turno estavam aptos a votar 1.823 eleitores. Dentre estes estavam inscritos: presos provisórios, adolescentes internados, funcionários dos estabelecimentos prisionais e os mesários (TSE, 2016b).

16 Para fins de comparação: em 2010 havia 152 mil presos provisórios e 15.500 adolescentes internados para 20.099 eleitores (12\%). Em 2012 e 2014, o número de eleitores caiu: aproximadamente 10.000 e 15.000, respectivamente. Já em 2016, havia 292.450 presos provisórios e 18.567 adolescentes internados para 5.973 votantes (2\%). Números preocupantes, pois a quantidade destes votantes tem caído. Justificativa geralmente se pauta em questão de segurança e deficiência em logística. Também se pode considerar o desinteresse do próprio indivíduo sob privação de liberdade ï o que requer trabalho de conscientização.
} 
e preservam seus direitos intactos. Assim é muito justo que eles possam votar. Negar esse direito é um mal irreparável, uma vez que absolvido no final do processo não há mais como recuperar o direito negado.

Quando o significado do ato de votar é meramente eleitoreiro, como no ñvoto de cabrestoà processo no qual o voto do eleitor constitui-se enquanto moeda de troca por dinheiro, gratificação, cargo ou vantagens (interesses particulares), bens patrimoniais, degrada-se o eleitor e a democracia representativa. Além de ilegal e antiético, nesse processo não se pensa no sentido coletivo do voto, nem na busca por melhorias sociais e sim naquilo que imediatamente Ihe trará retorno, o r̃qui e agoraò alienando o ato de votar e recheando esse ato de atraso e ignorância.

Além disso, o descrédito com a política evidenciado pela indignação com a corrupção e o descaso do poder público em atender as graves demandas sociais, tem estimulado o voto de protesto, em que o eleitor vota em candidatos por ironia, simpatia pessoal, ou provocada pela propaganda eleitoral de rádio e tv, sem nenhuma proposta, significando $\mathrm{o}$ ato de votar de forma irreverente, irônica e alegórica.

$O$ ato de votar irreverente, não indicando nenhum político tradicional, é uma ironia em que o eleitorado ao assistir a falta de atuação do político que possui o mandato sem realmente representar os interesses de seus mandatários, senão os dele e de seus correligionários, acaba por procurar um inovador, mesmo que seja um ídolo popular, um palhaço, com promessas falaciosas.

Votar não é fácil, pois, a corrupção eleitoral que envolve o político ou candidato ao cargo eletivo que, sem escrúpulos, corrompe o eleitor para se eleger e o próprio eleitor que troca seu voto por favores pessoais, atenta contra a democracia representativa. Nesse sentido, defender o voto dos presos preventivamente e adolescentes infratores maiores de 16 anos é significar o ato de votar como um processo inclusivo e de construção de cidadania.

Essas considerações nos oferecem condições para compreender que o ato de votar e o exercício da cidadania plena estão intrinsecamente ligados ao desenvolvimento humano e suas relações com o sistema representativo, no contexto de um Estado pouco popular, quanto a pauta das minorias. Portanto, o significado e conceito de votar não é determinado universalmente e sua compreensão varia no tempo e no espaço, modificando-se a depender do jogo de interesses econômicos e políticos.

No entanto, certos elementos sociais intrínsecos a esses conceitos desde os primórdios da civilização, como a desigualdade, exclusão, lutas sociais e falta de educação, acabam por dificultar e desafiar o cidadão em sua sobrevivência e na consolidação de seus direitos. A evolução do significado de cidadania e direito ao voto, acompanhou as mudanças de nossa sociedade, juntamente com a passagem da educação no Sistema prisional como um dos direitos oriundos da cidadania e promotora desta. 
A civilização se dá justamente a partir da ressignificação do conceito de direito ao voto, significado como inclusão no sistema de poder da sociedade. De acordo com Brzezinski e Santos (2015, p. 14), rả cidadania se aprende, mas, sobretudo, se conquistaò e a educação surge como o principal meio para essa conquista. Entretanto, se questiona que cidadãos estão se formando no Sistema prisional e se realmente as escolas possuem capacidade para desenvolver a autonomia e efetiva reintegração social.

Como resultado pode-se afirmar que as justificativas e argumentos que procuram negar aos presos provisórios e adolescentes infratores o direito ao voto, ancoram-se numa representação social desses sujeitos como aqueles que não merecem ter e, muito menos, exercer seus direitos de cidadania. Baseiam-se no paradigma da retirada de direitos como punição pelos supostos crimes ou delitos cometidos.

Por outro lado, os argumentos a favor do direito ao voto dos sujeitos em questão alicerçam-se numa imagem do preso provisório e adolescente infrator como não condenados juridicamente, sendo, portanto, cidadãos portadores de quase todos os seus direitos. Nesse sentido, supõe-se que para a possibilidade de uma real reinserção social dos encarcerados faz se necessário, através do processo educativo, colocar ao seu alcance a consciência dos seus deveres e direitos.

\section{Referências}

BOBBIO, Norberto. O futuro da democracia. Tradução de Marco Aurélio Nogueira. São Paulo: Paz e Terra, 2000.

BRASIL. Código Eleitoral. Código Eleitoral Anotado e Legislação Complementar. $12^{\mathrm{a}}$ ed. - Brasília, DF: Tribunal Superior Eleitoral (Secretaria de Gestão da Informação), 2016.

ï ï ï ï ï ï ï ï ï ï ï . Constituição (1988). Miniconstituição Federal. 1를 - Indaiatuba, SP: Editora Foco Jurídico, 2017.

i i i i ï ï ï ï ï ï ï ï. Ministério da Justiça (Departamento Penitenciário Nacional). Levantamento Nacional de Informações Penitenciárias INFOPEN - junho de 2016. Disponível em: $<$ http://www.justica.gov.br>. Acesso em: jun. 2018.

їїїїїїїїї. Ministério dos Direitos Humanos (Sistema Nacional de Atendimento Socioeducativo - SINASE). Levantamento Anual SINASE 2016. Disponível em: <http://www.mdh.gov.br>. Acesso em: jun. 2018. 
ï ї ї ї ї ї ї їїï. TSE ï Tribunal Superior Eleitoral. Resolução n. 22.712, de 2008. Dispõe sobre os atos preparatórios, a recepção de votos, as garantias eleitorais, a totalização dos resultados e a justificativa eleitoral. Brasília, 2008.

ї ї ї ї ї ї ї ї̈̈ . TSE İ Tribunal Superior Eleitoral. Presos Provisórios têm não só o direito, mas o dever de votar (Audiência Pública do TSE). Brasília, 2010a.

ï ï ï ï ïïïïïï . TSE ï Tribunal Superior Eleitoral. Resolução n. 23.219, de 2010. Dispõe sobre a instalação de seções eleitorais especiais em estabelecimentos penais e em unidades de internação de adolescentes e dá outras providências. Brasília, 2010b.

ï ï ï ï ï ï ï ï ï ï . TSE ï Tribunal Superior Eleitoral. Resolução n. 23.461, de 15 de dezembro de 2015. Brasília, 2015.

i i ï ї ї ї ї ї ї ї. TSE Ï Tribunal Superior Eleitoral (Tribunal da Democracia). Faltam 11 dias: presos provisórios e adolescentes internados vão votar em 121 seções especiais. Brasília, 2016a. Disponível em: <http://www.tse.jus.br/imprensa/noticiastse/2016/Setembro/faltam-11-dias-presos-provisorios-e-adolescentes-internados-vao-votarem-121-secoes-especiais>. Acesso em: set. 2017.

ï ï ï їїїїїїїïï. TSE ï Tribunal Superior Eleitoral (Tribunal da Democracia). Segundo turno: mais de mil presos provisórios participaram da votação. Brasília, 2016b. Disponível em: <http:/www.tse.jus.br/imprensa/noticias-tse/2016/Setembro/faltam-11-diaspresos-provisorios-e-adolescentes-internados-vao-votar-em-121-secoes-especiais $>$. Acesso em: set. 2017.

ï ï ï ї їїїїїї̈. TSË̈ Tribunal Superior Eleitoral. Resolução n. 23.554, de 18 de dezembro de 2017. Brasília, 2017.

BRZEZINSKI, I.; SANTOS, C. A. Sentido e significados da política: ação e liberdade. Brasília: LiberLivro, 2015.

CAMARGO, Juliana Lobo. O exercício do direito de voto e a participação do preso provisório no processo eleitoral na sociedade brasileira e catarinense. Resenha Eleitoral: v. 17, 2009. 
CHAUI, Marilena. Convite à Filosofia. São Paulo: Editora Ática, 2000.

CANIATO, Ângela. Da subjetividade sob sofrimento narcísico numa cultura da banalidade do mal. Em CLONER, Katia Simone. et al. (Orgs.), Ética e paradigmas na psicologia social. Porto Alegre: ABRAPSO Sul, 2003. p. 60-74.

CARDOSO-JUNIOR, Hélio Rebello. Ontopolítica e diagramas históricos do poder: maioria e minoria segundo deleuze e a teoria das multidões segundo Peirce. Veritas (Porto Alegre. Impresso), v. 57, p. 153-179, 2012.

COSTANZE, Bueno Advogados. Preso X Cidadania - Direito ao voto. Bueno e Costanze Advogados, Guarulhos, 30.04.2008. Disponível em: <http://buenoecostanze. adv.br/index.php?option=com_content\&task=view\&id=868\&ltemid=27 >. Acesso em $30 / 12 / 2008$.

LAKATOS, Eva Maria; MARCONI, Marina de Andrade. Fundamentos de metodologia científica. 7. ed. São Paulo: Atlas, 2003.

MOSCOVICI, Serge. Representações Sociais: Investigações em Psicologia Social. Trad. Pedrinho A. Guareschi. 6 ed. Petrópolis: Vozes, 2009.

ROSA, Miriam Debieux.; VICENTIN, Maria Cristina Gonçalves. Os intratáveis: o exílio do adolescente do laço social pelas noções de pericolosidade e irrecuperalidade. Revista Psicologia Política (Impresso), v. 10, p. 107-124, 2010.

ROSO, Adriane; STREY, Marlene Neves; GUARESCHI, Pedrinho; BUENO, Sandra M. Nora. Cultura e ideologia: a mídia revelando estereótipos raciais de gênero. Psicologia \& Sociedade, v.14, n. 2, p.74-94, 2002.

RANGEL-JUNIOR, José Carneiro, NOBREGA, Adriano César Oliveira. Os direitos políticos do preso provisório: uma análise da (im) possibilidade do voto, Revista de teorias da democracia e direitos políticos, v. 4, n. 1, p. 39-55, 2018.

SILVA, José Afonso da. Comentário contextual à constituição. $2^{a}$ ed. - São Paulo: Malheiros, 2006.

WEBER, Max. Ciência e Política: duas vocações. Tradução de Leonildas Hegenberg e Octany Silveira da Mota. São Paulo: Editora Cultrix, 2000. 